\title{
Challenges in the end-of-course paper for nursing technical training
}

\author{
Desafios do trabalho de conclusão de curso na formação do técnico de enfermagem \\ Desafíos del trabajo de conclusión de curso en la formación del técnico de enfermería
}

\begin{abstract}
Adriana de Oliveira', Maria José Sanches Marin', Elisabete Takeda', Osni Lázaro Pinheiro'
' Faculdade de Medicina de Marília, Master's Degree in Health Education. Marília, São Paulo, Brazil.
\end{abstract}

How to cite this article:

Oliveira A, Marin MJS, Takeda E, Pinheiro OL. Challenges in the end-of-course paper for nursing technical training. Rev Bras Enferm [Internet]. 2017;70(6):1212-9. DOI: http://dx.doi.org/ 10.1590/0034-7167-2016-0105

Submission: 04-01-2016 Approval: 02-20-2017

\section{ABSTRACT}

Objective: To verify the opinion of Nursing Technical Training students on the stages of construction of the End-of-Course Paper. Method: A cross-sectional study with a qualitative and quantitative approach. A total of 94 students participated from a Nursing Technical course of an institution in the State of São Paulo. A questionnaire was used with assertions, followed by a "Likert Scale" and open field for additional comments. Results: The students gave a positive evaluation of the stages involved in completing the paper, but negative responses regarding the time available and obligatory nature $(38 \%)$. Nevertheless, they understood the essence of the task, in order to foster personal and professional growth; with perspectives to advance in other modalities of the course. Conclusion: It is important that course administrators and professors are prepared to support their students, aiming at an effective transformation for the way of thinking and practice in health care.

Descriptors: Teaching; Monograph; Nursing Technician; Students; Support for Human Resources Development.

\section{RESUMO}

Objetivo: Verificar a opinião dos estudantes do Ensino Técnico de Enfermagem sobre as etapas de construção do trabalho de conclusão de curso. Método: Estudo transversal, com abordagem qualitativa e quantitativa. Participaram 94 estudantes do curso Técnico de Enfermagem de uma instituição do Estado de São Paulo. Foi utilizado um questionário com assertivas, seguidas por uma "Escala Likert" e campo aberto para comentários adicionais. Resultados: Os estudantes avaliaram positivamente a realização das etapas do trabalho de conclusão de curso, exceto o tempo disponível e sua obrigatoriedade. Eles apreenderam a essência da construção desse trabalho, no sentido de propiciar crescimento pessoal e profissional, com perspectivas para avançar em outras modalidades de curso, embora 38\% não concorde com a obrigatoriedade dessa construção. Conclusão: É importante que gestores e docentes estejam preparados para apoiar os estudantes, visando a efetiva transformação na forma de pensar e agir em saúde.

Descritores: Ensino; Monografia; Técnico de Enfermagem; Estudantes; Apoio ao Desenvolvimento de Recursos Humanos.

\section{RESUMEN}

Objetivo: Verificar la opinión de los estudiantes de la Enseñanza Técnica de Enfermería sobre las etapas de construcción del trabajo de conclusión de curso. Método: Estudio transversal, con abordaje cualitativa y cuantitativa. Participaron 94 estudiantes del curso Técnico de Enfermería de una institución del Estado de São Paulo. Fue utilizado un cuestionario con asertivas, seguidas por una "Escala Likert" y campo abierto para comentarios adicionales. Resultados: Los estudiantes evaluaron positivamente la realización de las etapas de trabajo de conclusión de curso, excepto el tiempo disponible y su obligatoriedad. Ellos asimilaron la esencia de la construcción de ese trabajo, en el sentido de propiciar crecimiento personal y profesional, con perspectivas para avanzar en otras modalidades de curso, aunque 38\% no concuerde con la obligatoriedad de esa construcción. Conclusión: Es importante que gestores y docentes estén preparados para apoyar a los estudiantes, visando la efectiva transformación en la manera de pensar y reaccionar en salud.

Descriptores: Enseñanza; Monografía; Técnico de Enfermería; Estudiantes; Apoyo al Desarrollo de Recursos Humanos. 


\section{INTRODUCTION}

In view of the current National Health Policy, the role of the Nursing team has gained great prominence, both by the attributions that are appropriate to it and by the contingent of professionals of this area that compose the health team. In this context, the nursing technician, who is assigned the role of direct care for the user, is essential to health actions. Thus, investments in their training are justified, especially considering the mishaps of its trajectory, throughout history ${ }^{(1)}$.

The origin of Nursing was characterized by the emphasis on the art of human care exercised essentially by religious women with a charitable character. The professionalization of this act was officially recognized by society in the nineteenth century, when an incessant search began for the construction of a field of science focused on the issues inherent to care at individual, collective and family levels ${ }^{(2)}$.

This began with Florence Nightingale's work in the Crimean War, for having stood out in the definition and implementation of principles of care that contributed to a reduction in the soldiers' mortality. In addition, the social division of labor was initiated, since at that time, the denomination "Lady nurses" was attributed to professionals belonging to the high class of society and these were responsible for the activities of supervision and organization of the work; whereas "Nurses" destined to manual tasks and direct care were from lower socioeconomic levels and submissive to those of a higher level ${ }^{(3)}$.

Throughout history, nursing practices were influenced by the capitalist model of production, which reinforced fragmentation of the work process and division of tasks. Consequently, the nursing auxiliaries and technicians gave the most direct care, such as administration of medications, applying dressings, feeding and bathing ${ }^{(4)}$.

It is important to consider that the training of the nursing technician has undergone transformations driven by the National Curricular Guidelines for professional education, through the conception oriented by competence, which seeks the development of skills inherent to the world of work ${ }^{(5)}$.

In the area of health, faced with a significant contingent of mid-level professionals in the work context and taking into account that the main characteristic of their practice is to preserve the life and health of the person, family and community, founded on human and ethical principles, and having as its essence the interpersonal relationship, investment in the formation of this professional category becomes essential ${ }^{(6)}$.

For this, the teaching processes should be implemented, based on methods that value critical-reflexive learning, starting from the daily practice of health. An example of this is the Professionalization Program for Nursing Workers (Profae), the purpose of which is training and qualification, focused on the valorization of professionals, aiming, on the one hand, to humanize and improve care and on the other, to stimulate the expansion of opportunities for large contingents of workers who can dedicate themselves to the conscientious and responsible exercise of the profession ${ }^{(7-8)}$.

The National Curricular Guidelines for Technical Vocational Education, defined by Resolution no. 6 of September 20, 2012, classify the Nursing technical course and propose as a guiding principle the identity of the professional profiles, added to the set of knowledge, skills and wisdom, linked to technological, social, economic and environmental development ${ }^{(9)}$.

In the State of São Paulo, it is possible to highlight an educational center with links to the state government that has 218 technical schools and is considered the largest technical education center in Latin America. This institution is home to 57 Nursing technical courses, and is therefore a center responsible for the training of human resources of a technical nature in the Nursing sector ${ }^{(10-11)}$.

The pedagogical project of the Nursing technical course of the referred educational center defines, as a primary objective, the development of the students in the scope of the general competences of the health area, as well as in the specific mediumlevel technical skills. The philosophical ideals of this institution recognize the importance of preparing the student for the new political and social context, establishing the guideline of the principles of integrality and humanization of care, in the biopsychosocial dimensions of the human being ${ }^{(11)}$.

Through training, the Nursing technician can act in the promotion, prevention, recovery and rehabilitation of health-disease processes, both individually and collectively. In this way, this professional is qualified to work in the various health care settings and in all phases of the life cycle, while always integrated to an interdisciplinary team, with a critical, reflexive and ethical vision of Nursing care $^{(11)}$.

In a continuous process of curricular development since 2007, the End-of-Course Paper (ECP) has been incorporated into the course plan as a mandatory condition to obtain the professional technician degree. This aims for a greater approximation to the world of work and the development of critical thinking. The process of developing ECP allows the training of creative professionals capable of attending the diverse demands imposed in professional practice ${ }^{(12)}$.

This innovation has brought within the technical education institution an element of the training process that hitherto was institutionalized only in the graduate Nursing courses $^{(13)}$. In the field of technical education, this initiative represents a challenge that requires a better understanding. However, it is certain that this activity is of great significance, since it is a tool that enables reflection on the work process and the instrumentalization of professionals for the necessary changes in the model of health care centered on biological aspects and technical procedures. The scientific literature has few works focusing on the experiences of ECP in technical courses, mainly because it is a recent activity.

This activity has great relevance in developing the students' professional training; consequently it is also necessary for the professors to be prepared and available to support the students in this process. The student, when adapting to a new curricular structure, loses the fear of innovation, learns to solve problems and becomes active, in the learning process. However, there are many difficulties and challenges to be faced, because ECP has the characteristics of a differentiated work, following scientific criteria, and requiring logical reasoning and creativity ${ }^{(11)}$. In the realization of an ECP, there are processes that can cause difficulty; these can be internal or external. Among the factors, it is important to emphasize the difficulty of access to the library, the scarcity of material available, deficits in orientation due to the work overload of professors, the responsibility with other disciplines of the 
curriculum and defense of ECP with the examining board comprised of professors ${ }^{(14)}$.

In contrast, some factors appear to facilitate the work. Among these, we highlight the choice of a theme that is agreeable for the researcher, the student's access to sources of consultation and the methodology. In the institutional context, the support of the course professors, tutoring, and an adequate and up-to-date library constitute other processes beneficial to the development of the work ${ }^{(15)}$. Thus, in view of the curricular changes in Nursing technical courses, the need arises to carry out an investigation to identify the repercussions from incorporating ECP into the curriculum of these courses. Initially by asking what is the perception of the student in relation to the different stages of its elaboration. In this sense, the objective proposed here is to verify the perception of the various stages of ECP among Nursing Technical Program students.

\section{METHOD}

\section{Ethical aspects}

The study was approved by the Ethics Committee in Research Involving Human Beings of the Marília School of Medicine Famema. All the participants were oriented regarding the research objectives and signed the Informed Consent Term.

\section{Design, study location and period}

A descriptive, cross-sectional research with a quantitative-qualitative approach was carried out. The study took place in what is considered to be the largest technical education center in Latin America, comprising 218 ETECs [State Technical Schools], distributed throughout the State of São Paulo, and 57 technical education units that offer technical courses in Nursing. The ETECs are organized from 16 administrative regions; two of these, however, do not offer a nursing course ${ }^{(10)}$. Data collection took place from July to September 2014 and was realized by the principal researcher.

In the units of the technical-level educational center where the study was carried out, the ECPs are developed according to the assumptions of scientific methodology, during two semesters, starting with the planning and definition of the subject, up until the presentation of the paper to an examining board. The work is developed in groups of three to four students, mediated by a course tutor and following interdisciplinary principles, articulating the day-to-day activities and experiences of the student, in order to collaborate towards the construction of knowledge ${ }^{(16)}$.

\section{Sample}

For the sample definition, a unit of the educational center was selected by lottery for the administrative region and the inclusion criterion was offering a Nursing technical course. From a total of 14 units drawn, nine accepted to participate in the study and were represented by letters $A$ to I. The total number of students enrolled in the fourth module of the Nursing technical course was invited to participate in the study, amounting to a total of 234; of these, 94 students effectively participated in the study, thereby reaching a representative sample of $40.2 \%$.

\section{Study protocol}

After the selection of the units, a telephone contact was made with each of the coordinators of the Nursing technical courses in the units participating in the study, with the intention of explaining the purpose of the study. When course coordinators agreed to the work, an invitation letter was sent to all the students officially enrolled in the fourth module of the Nursing technical course. The letter of invitation presented a link that directed the respondent to an electronic platform known as "SurveyMonkey ${ }^{\circledR "}$ and provided the respective password to access the platform.

The instrument used to collect data contained 15 assertions related to the process of preparing the ECP, which was adapted from the tool developed by Ramos ${ }^{(17)}$. The assertions were answered using a Likert Scale with five alternatives, varying between "totally agree" and "totally disagree". At the end of the instrument, an open field was made available, containing the "Additional Comments on ECP" question, which allowed students to report other information they felt was important to include.

\section{Results and statistical analysis}

The quantitative data of the instrument were described in percentage frequency and analyzed by chi-square test. The results were considered statistically significant when $p \leq 0.05$.

The qualitative approach of the study is related to the data obtained in the open fields of the questionnaires, which were analyzed according to the Content Analysis Technique - Thematic Modality $^{(18)}$.

The organization of the material obtained in the additional statements was done in stages, taking into account the different phases of the methodological framework adopted in this study, i.e., reading, units of analysis, categorization and thematic formation. The analysis of the subjects contemplated understanding through the inference and interpretation of the participants' statements, revealing those significant to ECP, in four aspects: ECP contributing to professional training and future advances, ECP conceived as unnecessary to nursing technical teaching, insertion of ECP in the course context and interpersonal relationships permeating the construction of ECP.

\section{RESULTS}

The majority of students were female, between the ages of 18 and 20 years, engaged in professional activity and 33 (35.1\%) working in the Nursing sector, as shown in Table 1.

Table 1 - Sociodemographic characterization of the study participants, N = 94, Marília, São Paulo, Brazil, 2015

\begin{tabular}{lccc}
\hline Characteristics & Variable & $\mathbf{n}$ & $\mathbf{( \% )}$ \\
\hline Sex & Female & 81 & 86 \\
& Male & 13 & 14 \\
Age group (yrs) & $18-20$ & 48 & 51 \\
& $21-30$ & 24 & 26 \\
& $31-40$ & 12 & 13 \\
& $41-50$ & 06 & 06 \\
Exercises professional activity & $51-60$ & 04 & 04 \\
Activity in the field of the course & Sim & 49 & 52 \\
& Sim & 33 & 35.1 \\
\hline
\end{tabular}


Table 2 - Opinion of the students in relation to the End-of-Course Paper (ECP) in the Nursing technical course $(\mathrm{N}=94)$, Marília, São Paulo, Brazil, 2015

\begin{tabular}{|c|c|c|c|c|}
\hline \multicolumn{2}{|r|}{ Assertions } & \multicolumn{3}{|c|}{$\begin{array}{c}\text { Frequency } \\
(\%)\end{array}$} \\
\hline & & $\mathbf{C}^{*}$ & $\mathbf{I}^{*}$ & $\mathbf{D}^{*}$ \\
\hline 01 & I received clear guidance on the purpose and preparation of the $\mathrm{ECP} * *$ & $89^{\mathrm{a}}$ & $9^{b}$ & $2^{\mathrm{b}}$ \\
\hline 02 & The choice of theme was guided by the teacher & $61^{\mathrm{a}}$ & $13^{\mathrm{b}}$ & $27^{c}$ \\
\hline 03 & Delimitation of the topic was a quick step in ECP planning & $64^{\mathrm{a}}$ & $14^{\mathrm{b}}$ & $22^{c}$ \\
\hline 04 & All the curricular components collaborate in some way to choose the theme of the work & $64^{\mathrm{a}}$ & $16^{\mathrm{b}}$ & $20^{c}$ \\
\hline 05 & One of the reasons for choosing the theme was the experiences in the field of clinical experience & $59^{\mathrm{a}}$ & $22^{\mathrm{b}}$ & $19^{c}$ \\
\hline 06 & The reason for choosing the theme was the social reality and health scene & $83^{\mathrm{a}}$ & $14^{\mathrm{b}}$ & $3^{\mathrm{b}}$ \\
\hline 07 & The school library is up-to-date and easily accessible & $65^{\mathrm{a}}$ & $17^{\mathrm{b}}$ & $18^{\mathrm{c}}$ \\
\hline 08 & I have computer skills needed to format the work & $61^{\mathrm{a}}$ & $23^{\mathrm{b}}$ & $16^{\mathrm{c}}$ \\
\hline 09 & Realizing ECP is contributing to your personal growth & $83^{\mathrm{a}}$ & $13^{\mathrm{b}}$ & $4^{\mathrm{b}}$ \\
\hline 10 & Two semesters are enough for the ECP & $44^{\mathrm{a}}$ & $16^{\mathrm{b}}$ & $40^{c}$ \\
\hline 11 & I experienced feelings of fear, frustration and incapacity while preparing the ECP & $77^{\mathrm{a}}$ & $11^{\mathrm{b}}$ & $13^{\mathrm{b}}$ \\
\hline 12 & Time is spent outside classes for preparing the ECP of more than one hour & $80^{\mathrm{a}}$ & $12^{\mathrm{b}}$ & $9^{b}$ \\
\hline 13 & Affinity with the course tutor is satisfactory & $87^{\mathrm{a}}$ & $12^{\mathrm{b}}$ & $1^{\mathrm{b}}$ \\
\hline 14 & Management and coordination are supportive for the ECP preparation & $70^{\mathrm{a}}$ & $24^{\mathrm{b}}$ & $5^{\mathrm{b}}$ \\
\hline 15 & The exchange of experiences between the students was stimulated during the work development process & $82^{\mathrm{a}}$ & $13^{\mathrm{b}}$ & $5^{\mathrm{b}}$ \\
\hline 16 & I agree with the compulsory ECP in technical education & $44^{\mathrm{a}}$ & $18^{\mathrm{b}}$ & $38^{c}$ \\
\hline
\end{tabular}

Note: ${ }^{*} \mathrm{C}=$ Agreement Pole (totally agree + agree); I (Indifferent); $D=$ Disagreement Pole (disagree + totally disagree). Different letters on the same line represent statistically significant differences $(p \leq 0.05)$. Equal letters on the same line no statistically significant difference $(p \geq 0.05)$ between them; $* *$ End-of-Course Paper (ECP)

Table 2 shows the results of the evaluation of items that make up the ECP construction process. To facilitate its visualization, a grouping of the data was prepared in agreement poles, in order to indicate the answers "totally agree" and "agree"; while at the other end the disagree pole was created, encompassing the "totally disagree" and "disagree" alternatives. The neutral category was maintained according to the original proposal.

It can be observed that, in all items of the instrument, the participants gave responses that approached the poles of agreement, with a statistically significant difference from the other options in the instrument. Although the students also significantly agreed with the assertions, "Two semesters are sufficient for ECP" and "I agree with the compulsory completion of the course in technical education" ( $p=0.001)$. These were the aspects that most mobilized a division of opinions among students, with disagreement reaching approximately $40 \%$ (Table 2 ).

From the computation of data contained in the open question, it was possible to construct four categories that, in many aspects, reinforce the results obtained with the quantitative analysis from the closed questions, as described below.

\section{The End-of-Course Paper as a contribution to vocational training and future advances}

Students pointed out that ECP contributes to the learning process as it encourages reading, assists the pursuit of an academic career, and encourages future research projects. The following statements illustrate these opinions:

\section{$[\ldots] I^{\prime} m$ learning from $E C P, I^{\prime} m$ reading more [...]. (E4 B)}

This is an important step for student training; In addition to investigating a theme, it prepares us for when we go to college. (E 17 C)

The End-of-Course Paper is a good project that assists personal growth and in the field of work [...]. (E26 C)

The End-of-Course Paper considered as unnecessary for Nursing technical teaching

While some students express the importance of ECP in the training of the Nursing technician, others do not identify this need, stating that it should be optional. For them, the rules and norms required for this work make no difference to vocational training. They reveal difficulties with the short time to complete ECP, considering their complexity, in addition to finding that the time spent with ECP would be better utilized in practical activities that are directly related to what they will perform in their professional life.

[...] the computer part helps and gives us some notions of formatting. ECP and its rules and structures make no difference whatsoever. (E 14 C)

[...] ECP does not help at all in student training; should be for those who are going to college, because they have more time to develop the work, because for the technician the time is too long to develop such a complex task. (E $23 \mathrm{C}$ )

I find it unnecessary to apply the End-of-Course Paper in technical courses, because what will count most in the end are the clinical experiences that will help the student to 
develop the techniques taught in the classroom and laboratory. The course would be much better if they switched ECP schedules to more clinical experiences. (E 24 C)

\section{Insertion of the End-of-Course paper in the context of the course}

The students of the technical course indicate that the period for developing the ECP is not enough for this to occur to their satisfaction, and the fact that the clinical experience occurs concomitantly impedes greater benefits from this activity.

[...] Since it is obligatory, it could start already in the first module so that the stress entailed is distributed throughout the course and not only at the end [...]. (E26 C)

I think that technical education is a very short period for a study as in depth as the ECP. (E41 D)

[...] The clinical experiences are in the same periods in which the ECP is developing and ends up making learning difficult with the other subjects. $(\mathrm{E} 78 \mathrm{H})$

\section{Interpersonal relations permeating the construction of the End-of-Course Paper}

For the students who responded to the data collection instrument, the ECP construction provides both satisfactory and unsatisfactory relationships, either with colleagues in the group or with professors. It is added that, for them, the construction of ECP requires responsibility, patience and companionship, as well as developing affinities. On the other hand, there are disagreements, stress, a need for clearer guidelines and greater proximity between student and professor, as can be seen in the following statements:

[...] the relationship with colleagues in the group has more affinity. (E 4 B)

[...] it entails a lot of disagreement between the members involved and a lot of stress. (E19 C)

The preparation of an ECP requires a lot of teamwork and also clear orientation on its preparation, which leaves something to be desired. (E 93 I)

\section{DISCUSSION}

The present study allowed the promotion of relevant reflections on a topic not explored in the literature, since the construction of ECP in Nursing technical courses represents an innovation and a great challenge. Furthermore, even in undergraduate and specialization courses there are numerous difficulties for preparation of this work ${ }^{(19)}$.

Among the study participants, the majority of participants were between 18 and 25 years old and women, which reproduces the historical female bias in the Nursing workforce ${ }^{(3)}$.

Referring to the verification of students' perceptions regarding the stages of the construction of the ECP, there was agreement in relation to most of the assertions of the instrument. Initially, it was emphasized that guidelines on the purpose of implementing ECP were clearly communicated, which seems to be an important step forward in this construction. In the case of technical courses, these students probably have no approximation with the scientific method logic. As a result, the interdisciplinary work of the ECP course tutors, librarians and professors from other disciplines also contributes to reducing the students' fear and anxiety ${ }^{(20)}$.

Regarding the choice of subject for ECP, the responsibility of the professor goes beyond the transmission of knowledge about a certain topic, it also encompasses responsibility for awakening the student's interest in the object of research, thereby ensuring the learning process occurs in an effective manner ${ }^{(21)}$. Thus, at this stage, it is important that the course supervisor addresses the possibilities of research topics with the student, identifying the guiding question for elaboration of the ECP project ${ }^{(22)}$. For this choice to be effective, it is essential that the student is able to immerse himself/herself in the context of professional practice and recognize the problems. It is certain, however, that a scientific work in the Nursing technical courses needs to be directed with a level of complexity that allows its execution in the available time while, simultaneously, that there are advances in the capacity of reflection and search for innovations in professional practice ${ }^{(16)}$.

From this perspective, it is necessary to refer to the training of nurses for the execution of the teaching role, since the curricular matrix of the undergraduate courses, in most cases, does not contemplate contents pertinent to this exercise. Thus, in order to play their role, they take into account the models of professors from their graduation. This does not meet the current needs of the health system, which requires a questioning posture, capable of leading to a critical reflection on reality, mobilization of the students' protagonism and the proposal of intervention, aiming at transformation of health practices ${ }^{(22)}$.

Another important aspect with which the students agreed, when questioned, is the availability of library and computer knowledge. In addition, when stating that ECP aids personal and professional growth, it is possible to infer that different competencies are required, which reinforces the importance of the ECP development process. In this sense, the various stages that make up the ECP will bring the incorporation of secondary benefits to the student, geared towards a broader formation and with greater possibility of adaptation to the current world of work, which requires technical competence and critical and transformative capacity for the present scenario of health care $^{(11)}$.

It has been recognized that the execution of different stages of the scientific method stimulates the formation of professionals with a critical and reflexive vision, favoring the recognition of problems and thereby helping to implement improvements in health conditions ${ }^{(23)}$.

However, in order to adopt an obligatory ECP, it is necessary to make various investments, which, according to the specificity of the course, may require logistical, organizational and physical restructuring, such as construction or reform of laboratories, libraries and other academic spaces.

In this sense, there must initially be an opening of space in the curriculum to include contents that meet the needs of 
students with regard to the ECP. These contents can be worked through a single discipline or integrated into the various disciplines that compose the course curriculum ${ }^{(17)}$.

The ECP requirement in the Nursing technical course was the item in the data collection instrument for which the participants showed greatest disagreement. In the field for additional comments, this aspect was reiterated, which reinforces the controversy regarding this obligation.

The implementation of ECP presents some challenges, since the lack of preparation in research projects may be the first obstacle or difficulty encountered. The methodological rigor required by the work generates questions that require clear guidelines at each stage of the research methodology. However, through clarifications and successive approaches, it becomes possible to promote familiarization with the new form of research-based learning ${ }^{(24)}$.

Construction of the ECP, as well as pointed out in the statements of the students who participated in the present study, generated fear, frustration and a sense of incapacity, which does not differ from other teaching modalities that include a requirement for the preparation of an ECP. This is explained by the fact that it represents a new element, especially for high school students, since these emotions are natural in the face of a situation that, for the student, is considered unknown. Therefore, the challenge is to overcome obstacles in order to achieve the objectives ${ }^{(25)}$.

On the other hand, it was possible to identify in the students' statements, some elements of valorization of the use of this instrument in Nursing technical teaching. They can see that the incorporation of ECP in technical education contributes in a number of ways, including personal and professional growth and is useful for all those pursuing an academic career.

It is also worth underscoring that the construction of the ECP proposed by educational centers in the technical level of the study scenario, has a value in promoting teamwork. Teamwork on the one hand is now considered in a positive light, favoring exchanges and complementation of knowledge, while on the other hand sometimes as a difficulty. The focus on interpersonal relationships and teamwork is another important movement for current health education, since the complexity of care, the diversity existing in each reality of insertion of the professional, and the knowledge framework necessary for quality health care demand an interdisciplinary approach.

Teamwork requires the efforts of each member of the group, and especially without the effective participation of a leadership. In the statements, it was possible to observe that the students who positively evaluated the opportunity to work in a team were able to score aspects such as affinity, companionship and increase in results from the work. These aspects identified by the students are directly related to the team concept, in the sense of the diversity of members' abilities, multiple knowledge levels and interdisciplinary nature ${ }^{(26)}$.

In order to confront existing conflicts, mediation by the professor is imperative, allowing each individual to express his/her own point of view, to better resolve the conflict and avoiding difficulties in interpersonal relations from discouraging the entire team and interfering in the work $^{(21)}$. In this way, it is recommended that the members of the group should resolve their differences and the mobilization should be a joint effort. For this to occur, students should be guided and encouraged not to act individually, but to promote friendly and cooperative relationships ${ }^{(27)}$.

Referring to the relationship between course tutor and student, it is emphasized that it represents a starting point for the good progress of the research project. The empathy between professor and student can foster the creation of a work environment based on mutual respect and trust, in which there will be freedom to make criticisms and suggestions that will favor good planning and realization of the task ${ }^{(28)}$.

From a more structural point of view, respondents indicated that the time available for ECP is not sufficient to be developed to their satisfaction. It is worth mentioning that the incorporation of ECP into Nursing technical courses still represents a recent experience; however, by using the logic of the scientific method, this work is composed of stages that require the course tutor and student to be an organization process in which time is an element that cannot be neglected ${ }^{(17)}$.

\section{Study limitations}

The design of this work involved an institution with great impact in the training of nursing technicians, in the state of São Paulo; however, despite the efforts of the researchers, some units did not adhere to the study; likewise there was variability in the students' adherence within the participating units. In addition, it should be pointed out as a limitation of the study that the opinion portrayed involves only one participant in that process, represented by the student. In this sense, other studies could be implemented, incorporating the vision of teachers and course administrators.

\section{Contribution to Nursing and the health sectors}

The present study brings to the fore discussion on the training of mid-level Nursing professionals, in accordance with the principles and guidelines of the SUS [Unified Health System], which carries out actions with direct implications on the quality of care provided by the Nursing and health team.

\section{FINAL CONSIDERATIONS}

In the present study, the students presented different perceptions regarding the ECP as part of the requirements for training the Nursing technician, however the majority stated that they agree with the way in which it is developed in many of the aspects analyzed. They found this innovative proposal to be complex, but considered the steps of the scientific method, in addition to the norms and rules to which construction is subject to be a positive factor, leading to personal and professional growth, while opening perspectives to advances in other modalities of the course.

On the other hand, there were those who thought that the ECP is unnecessary, since the process is replete with norms and rules and consider that the short time available for the course would be better utilized on technical activities and clinical experience. 
Understanding the process of construction of ECP by students of technical education, although it seems contradictory, can be interpreted as inherent in the set of changes, where old and new models intertwine in a movement of advances and setbacks. It is important that administrators and professors of the technical courses maintain close supervision of the students' needs, with a view to offering support when necessary with the objective of putting into effect the proposal for transformation in the way of thinking and acting in health care practice.

\section{REFERENCES}

1. Machado $\mathrm{MH}$, Wermelinger M, Vieira M, Oliveira E, Lemos W, Aguiar Filho W, et al. Aspectos gerais da formação da enfermagem: o perfil da formação dos enfermeiros, técnicos e auxiliares. Enferm Foco[Internet]. 2016[cited 2015 Jul 08];6(2/4):15-34. Available from: http://revista.portalcofen.gov.br/index.php/enfermagem/article/view/687/297

2. Ferreira MA. Nursing art and science of care. Esc Anna Nery Rev Enferm[Internet]. 2011[cited 2014 Oct 15];15(4):664-6. Available from: http://www.scielo.br/pdf/ean/v15n4/en_a01v15n4.pdf

3. Soares MI, Souza Júnior DI, Lima KVD, Resck ZMR. Interface entre sistematização da assistência de enfermagem e o processo de trabalho da enfermagem: uma abordagem reflexiva. Rev Enferm UFPE[Internet]. 2013[cited 2014 Oct 15];7:7222-8 Available from: http://www.convibra.com.br/dwp.asp?id =4650\&ev $=25$

4. Menegaz JC, Kloh D, Martini JG, Reibinitz KS, Backes VMS, Zamprogna KM. Formação de nível médio em enfermagem: perspectivas na visão de estudantes de pós-graduação. Rev Enferm UFSM[Internet]. 2015[cited 2016 Oct 15];5(3):396-405. Available from: https://periodicos.ufsm.br/reufsm/article/view/17418/pdf

5. Brasil. Ministério da Educação. Conselho Nacional de Educação. Resolução CNE/CEB nº 04/99. Institui as Diretrizes Curriculares Nacionais para a Educação Profissional de Nível Técnico [Internet]. Brasília: Ministério da Educação; 1999 [cited 2015 Jul 08]. Available from: http://portal.mec.gov.br/setec/arquivos/pdf/RCNE_CEB04_99.pdf

6. Bassinelo GAH, Bagnato MHS. Project on a large scale: an analysis according to the existing bibliography. Esc Anna Nery Rev Enferm [Internet]. 2009[cited 2014 Oct 15];13(1):194-200. Available from: http://eean.edu.br/detalhe_artigo.asp?id=416

7. Cruz AMP, Almeida MA. Competencies in the education of Nursing Technicians to implement the Nursing Care Systematization. Rev Esc Enferm USP [Internet]. 2010[cited 2015 Jul 08];44(4):921-7. Available from: http://www.scielo.br/pdf/reeusp/v44n4/ en_09.pdf

8. Ferreira MA, Oliveira BGRB, Porto IS, Anborn CG, Castro JBA. O significado do Profae segundo os alunos: contribuição para a construção de uma política de formação profissional em saúde. Texto Contexto Enferm [Internet]. 2007[cited 2014 Oct 15];16(3):445-52. Available from: http://www.scielo.br/pdf/tce/v16n3/a10v16n3.pdf

9. Brasil. Ministério da Educação. Diretrizes Curriculares Nacionais para a educação profissional técnica de nível médio. Brasília (DF): Ministério da Educação; 2013.

10. Centro Paula Souza. ETEC: cursos técnicos [Internet]. São Paulo (SP): Centro Paula Souza; 2014[cited 2014 Oct 15]. Available from: http://www.centropaulasouza.sp.gov.br/cursos/etec/

11. São Paulo (Estado). Centro Paula Souza. Plano de Curso de enfermagem. São Paulo: Centro Paula Souza; 2012.

12. Bomfim MIRM. Formação docente em educação profissional técnica na área da saúde: trabalho, saúde e educação. Rio de Janeiro (RJ): Fundação Oswaldo Cruz; 2009. p. 75-88.

13. Santos VC, Anjos KF, Almeida OB. A percepção de formandos sobre a pesquisa em enfermagem no curso de graduação. Rev Enferm UFSM [Internet]. 2013[cited 2015 Jul 08];3(1):144-54. Available from: https://periodicos.ufsm.br/reufsm/article/view/7746/pdf

14. Trabalho de Conclusão de Curso: elementos inibidores e facilitadores: um estudo no curso de ciências contábeis em uma instituição de ensino superior filiada ao sistema ACAFE. In: Anais do III Congresso UFSC de Controladoria e Finanças; 2009 nov 5-7; Florianópolis, Brasil [Internet]. Florianópolis (SC): UFSC; 2009[cited 2014 Oct 15]. Available from: http://dvl.ccn.ufsc.br/ congresso/webroot/anais/3CCF/20090814154355.pdf

15. Cecílio S. Reflexões sobre a dimensão pedagógica do processo de orientação de monografia: a experiência junto ao curso de psicologia. Rev Prof Docente[Internet]. 2002 [cited 2013 Jul 08];2(6):1-17. Available from: http://www.revistas.uniube.br/index. $\mathrm{php/rpd/article/view/57/460}$

16. Ramos IML. Orientações gerais do TCC. São Paulo (SP): Centro Paula Souza; 2011.

17. Ramos IML. O trabalho de conclusão de curso no ensino técnico: um olhar sobre o processo de implementação [Dissertação]. São Paulo (SP): Centro Estadual de Educação Tecnológica Paula Souza; 2008.

18. Bardin L. Análise de conteúdo. São Paulo (SP): Edições 70; 2012.

19. Michelone APC, Tavares CMM, Marin MJS, Bernardo MCM, Tonhom SFR. Enfrentando o mito do trabalho de conclusão de curso junto aos especializandos: docentes do nível técnico. In: Fundação do Desenvolvimento Administrativo (FUNDAP). Trabalhos de Conclusão de Curso: TCCs selecionados. São Paulo (SP): Fundap; 2011. p. 65-8. 
20. Teterycz T, Littiere LF. Aspecto psicológico do serviço de orientação à normalização de trabalhos técnico-científicos. In: Anais XVI Seminário Nacional de Bibliotecas Universitárias; II Seminário Internacional de Bibliotecas Digitais; 2010 out 16-22; Rio de Janeiro, RJ [Internet]. Rio de Janeiro (RJ): UERJ; 2010[cited 2014 Oct 15]. Available from: http://www.sibi.ufrj.br/snbu2010/pdfs/ orais/final_297.pdf

21. Rodrigues J, Mantovani MF. The nursing professor and their representation about the professional formation. Esc Anna Nery Rev Enferm [Internet]. 2007[cited 2015 Jul 08];11(3):494-9. Available from: http://www.scielo.br/pdf/ean/v11n3/v11n3a15.pdf Portuguese

22. Lazzari DD, Silva GG, Espíndola DS, Martini JG, Backes VMS, Busana JA. Formação inicial de professores na enfermagem, fisioterapia e odontologia. Saude Transf Soc [Internet]. 2015[cited 2016 Oct 15];6(3):118-28. Available from: http://incubadora. periodicos.ufsc.br/index.php/saudeetransformacao/article/view/3038/4490

23. Santos VC, Anjos KF, Almeida OS. A percepção de formandos sobre a pesquisa em enfermagem no curso de graduação. Rev Enferm UFSM [Internet]. 2013[cited 2015 Jul 08];3(1):144-54. Available from: https://periodicos.ufsm.br/reufsm/article/view/7746/pdf

24. Liston PC, Silva MI. A importância da disciplina de metodologia científica na elaboração do trabalho de conclusão de curso-TCC nos cursos de graduação [Internet]. Rev Cient Fecra [Internet]. 2012 [cited 2013 Jul 08];1(1):1-10. Available from: http://www. fecra.edu.br/controle/paginas-revista/ed1/a_importancia_da_disciplina_de_metodologia_cientifica_na_elaboracao_do_trabalho_ de_conclusao_de_curso_-tcc_nos_cursos_de_graduacao.pdf

25. Rodrigues HKC, Cusatis Neto R. Estresse em alunos do $4^{\circ}$ ano expostos à realização do Trabalho de Conclusão de Curso (TCC). Col Pesqui Educ Fís [Internet]. 2010[cited 2014 Oct 15];9(2):111-8. Available from: http://www.editorafontoura.com.br/periodico/ vol-9/Vol9n2-2010/Vol9n2-2010-pag-111a118/Vol9n2-2010-pag-111a118.pdf

26. Piancastelli $\mathrm{CH}$, Faria HP, Silveira MR. O trabalho em equipe organização do cuidado a partir de problemas: uma alternativa metodológica para a atuação da equipe de saúde da família. Brasília (DF): OPAS; 2000.

27. Iale G. Os benefícios do trabalho em equipe: administrar conflitos e a importância do feedback nas organizações [Internet]. Administradores; 2010. [cited 2015 Jan 08]. Available from: http://www.administradores.com.br/artigos/carreira/ os-beneficios-do-trabalho-em-equipe-administrar-conflitos-e-a-importancia-do-feedback-nas-organizacoes/43583/

28. Cittadin J, Noni Junior A. Avaliação da relação ensino pesquisa na formação do ensino médio. In: Anais do II Congresso Internacional de Educação: Trabalho Docente, Interdisciplinaridade E Empreendedorismo Orleans; 2007 out 25-27. 